\title{
IVAN ILLICH CHEBANENKO
}

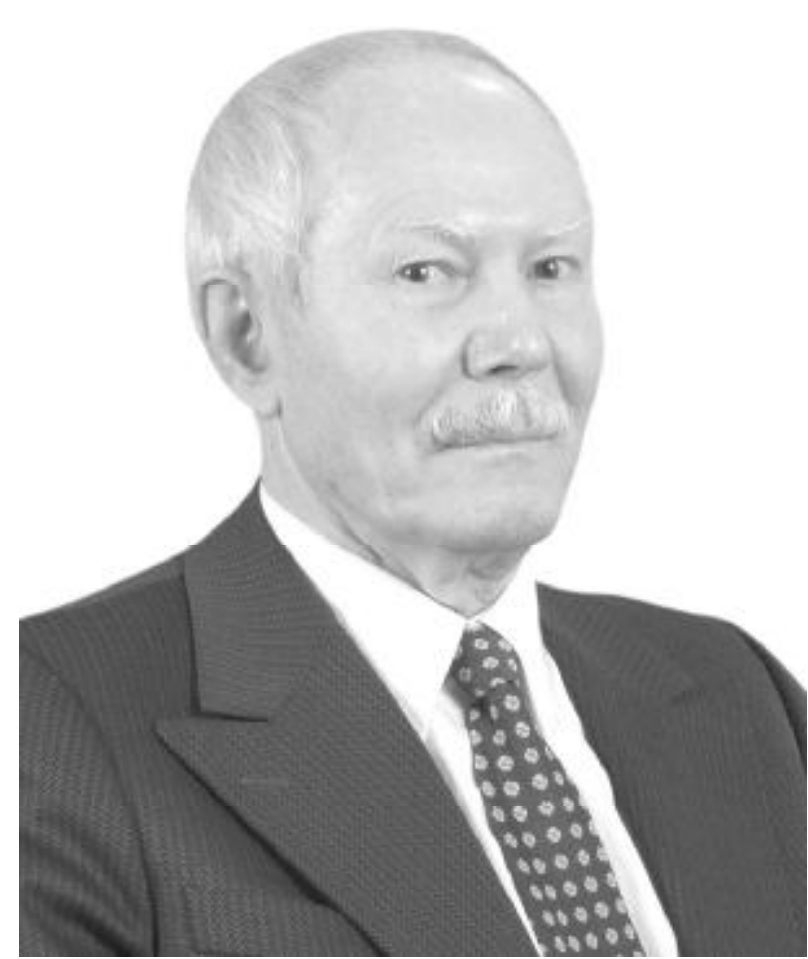

An outstanding Ukrainian scientist, geologist and tectonist, Doctor of Sciences in Geology and Mineralogy (1975), Professor (1979), Corresponding Member of the National Academy of Sciences (NAS) of Ukraine (1979), Full Member of the National Academy of Sciences of Ukraine (1982), Honored Scientist (1991), Deputy Director of the Institute of Geological Sciences of the Ukrainian Academy of Sciences (1972-1973, 1975-1978), Head of the Department of Geotectonics at the Institute of Geological Sciences (1978-present), State Prize of Ukraine in the field of science and technology (1992) Ivan I. Chebanenko celebrated his 85th anniversary.

Ivan I. Chebanenko was born on 31 March 1925 in Matviivka village (now part of Mykolaiv). He graduated from school before World War II. From 1944 until 1947 he served in the Soviet Army. In 1953 he graduated the Geological Department of the Odessa University and worked as a geologist in Donetsk region for two years. From 1955 until 1957 he studied at the Postgraduate School of the Institute of Geological Sciences. Having obtained the degree of a Candidate of Geological and Mineralogical Sciences he was sent to Czechoslovakia to take part in uranium-ore prospecting. In October 1960 he returned to Kyiv and started to work at the Institute of Geological Sciences as a research fellow (19601972), First Deputy Director of research (1972-
1973, 1975-1978), Head of a laboratory (19731975), and Head of the Department of Geotectonics (1978-present).

Ivan I. Chebanenko is a multidiscipline geologist. His works on the Geology of the Donetsk Coal Basin, geological structure and ore-bearing rocks of some regions of Czech crystalline massif are among his main scientific contributions. He studies mechanisms of development of dislocations with a break in continuity and dislocations by folding; tectonic processes in different regions of Ukraine and other countries; develops a theory of formation of planetary fault zones of the Earth's lithosphere and investigates the genetic connection of mineral deposits with zones of deep faults.

As a geologist and tectonist, Ivan I. Chebanenko became well-known for his monographs: "Basic patterns of fault tectonics of the Earth's crust" (1963), "Problems of folded zones of the Earth's crust (in the light of block tectonics)" (1964), "Fault tectonics of Ukraine" (1966) and "Faults of the Earth" (1969) where he concentrated on the problems of formation of planetary fault and plicate deformations of the Earth. Maps of ocean and continental faults, which were created by him for the first time in the world, helped draw a conclusion on a logical distribution of lithosphere faults of the Earth. In 1967-1968 this conclusion was supported by photos of the Earth's surface taken from space. It was an outstanding contribution to geological science.

These and his further studies resulted in developing of a new school in geology - doctrine of planetary faults of the Earth's lithosphere. This doctrine facilitated appearing of new concepts about crust's structure and its fault and block tectonics. The modern understanding of plate tectonics is developing on the basis of these concepts.

Theoretical foundations of geotectonics, problems of interaction of gravitational contraction forces with physicochemical development of the Earth's substance against the background of its rotational dynamics are considered in most of his works.

For the last two decades Ivan I. Chebanenko has studied interconnection of oil and gas deposits with deep fault zones of the Earth's crust. He supports the theory that some part of hydrocarbons is of inorganic origin that has originated in the subsurface.

Ivan I. Chebanenko and his supporters are the laureates of the State Award of Ukraine in Science and Technology (1992) awarded to them for active participation in the discovery of a new prospective object for oil and gas deposits on the basis of an inorganic hypothesis. 
Ivan I. Chebanenko is the author of more than 200 scientific publications including 14 monographs half of which concentrate on theoretical problems of lithosphere structure and its developing in a geohistorical aspect. These publications include: "Basic patterns of the fault tectonics of the Earth's crust and its problems" (1963), "Theoretical aspects of tectonic divisibility of the Earth's crust" (1977), "Structure and stages of development of the Dnieper-Donets trough-like depression" (1979), "Tectonics of North Prichernomorie" (1988), "Block tectonics of the crystalline basement of the DnieperDonets aulacogen" (1991).

No less important are his works on block tectonics and its role in oil and gas formation: "Search for hydrocarbons in the crystalline basement rocks" (1980), "Problems of oil-and-gas capacity of crystalline basement rocks of the Dnieper-Donets depression" (1991), "Oil-and-gas capacity of the Black Sea northwest shelf" (1995), "Oil-and-gas capacity of the Kerch-Taman shelf of the Black Sea, continental slope and deep-water basin of the Black Sea" (1996), "Oil-and-gas capacity of the north slope of the Dnieper-Donets depression" (1996),
"Oil-and-gas prospective objects of Ukraine: oiland-gas capacity of the basement of sedimentary basins" (2002), and many others.

Ivan I. Chebanenko takes an active part in scientific and organizational activities, public and political life of the Institute of Geological Sciences. He was a member of the International Scientific Council, the Scientific and Methodological Council of "Znannya" Society. Now he is a member of a number of professional councils. He always displays unflagging concern for training of high-class specialists.

$\mathrm{He}$ is the head of the Specialized Council at the Institute of Geological Sciences that supervises defenses of candidate and doctoral dissertations. As a scientific supervisor he has trained 10 candidates and 4 doctors of sciences.

Geological and scientific communities congratulate sincerely outstanding tectonist Ivan I. Chebanenko on his momentous anniversary and wish him health, new scientific ideas, new achievements and loving students. 